\title{
Moisture sorption characteristics of extrusion-cooked starch protective loose-fill cushioning foams
}

\author{
Maciej Combrzyński ${ }^{1}$,Leszek Mościcki ${ }^{1}$, Anita Kwaśniewska², Tomasz Oniszczuk ${ }^{1}$, Agnieszka Wójtowicz ${ }^{1}$, \\ Bartosz Solowiej ${ }^{3}$, Bożena Gtadyszewska ${ }^{2}$, and Siemowit Muszyński* \\ ${ }^{1}$ Department of Food Process Engineering, University of Life Sciences in Lublin, Doświadczalna 44, 20-280 Lublin, Poland \\ ${ }^{2}$ Department of Physics, University of Life Sciences in Lublin, Akademicka 13, 20-950 Lublin, Poland \\ ${ }^{3}$ Department of Milk Technology and Hydrocolloids, University of Life Sciences in Lublin, Skromna 8, 20-704 Lublin, Poland
}

Received December 13, 2016; accepted August 8, 2017

\begin{abstract}
A b s t r a c t. The aim of this work was to determine the water vapour sorption properties of thermoplastic starch filling foams processed by extrusion-cooking technique from various combinations of potato starch and two foaming agents: poly(vinyl) alcohol and Plastronfoam, in amount of 1, 2 and 3\% each. Foams were processed with the single screw extruder-cooker at two different screw rotational speeds 100 and 130 r.p.m. The sorption isotherms of samples were determined and described using the Guggenheim-Anderson-de Boer model. Also, the kinetics of water vapour adsorption by foams, as a function of time, was measured and fitted with Peleg model. On the basis of the analysis the influence of the applied foaming agents, as well as the technological parameters of extrusion-cooking process in relation to water vapour adsorption by thermoplastic starch foams was demonstrated. There was no difference between the shapes of the isotherms for poly(vinyl) alcohol foams while for Plastronfoam foams a notable difference among foams extruded at 100 r.p.m. was observed in the regions of low and high humidity content. The analysis of the Guggenheim-Anderson-de Boer model parameters showed that the water molecules were less strongly bound with the foam surface when extruded at a lower screw speed.

$\mathrm{K}$ e y w o r d s: extrusion-cooking, thermoplastic starch foams, protective loose-fill materials, sorption isotherms, foaming agents
\end{abstract}

\section{INTRODUCTION}

Extrusion-cooking is a technique of fast and intensive processing of materials in which the pressure and temperature of the process have a great influence on the characteristics of the final products (Agbisit et al., 2007; Chanvrier et al., 2013; Conti e Silva et al., 2010; Ilo et al.,

*Corresponding author e-mail: siemowit.muszynski@up.lublin.pl
1999; İbanoğlu et al., 2006). The temperature of the treatment during the process can be high (up to $c a .200^{\circ} \mathrm{C}$ ), the pressure can reach $20 \mathrm{MPa}$, while the total time is usually very short (30-45 s) (Combrzyński, 2012; Mitrus, 2012; Mościcki and Van Zuilichem, 2011; Suknark et al., 1997). Therefore, the extrusion-cooking process is an example of the so called HTST processes (high temperature, short time) (Frame, 1994; Guy, 2001; Lui and Peng, 2005; Mościcki and Van Zuilichem, 2011; Wójtowicz et al., 2013). Generally, the extrusion-cooking technique can be successfully applied to starch-based foam production (Altskär et al., 2008; Mitrus, 2012; Wang et al., 2005; Wu et al., 2010). The application of food extrusion-cookers gives much better results in processing of starch-based blends than conventional plastic extruders, due to the origin of plant components (Mitrus and Mościcki, 2014).

The types of used foaming agents, as well as the parameters of the extrusion-cooking process, such as temperature, screw rotation, raw material water content, have a direct impact on the density, porosity, mechanical parameters and other physical properties of obtained foams. For example, Van Soest et al. (1996) have shown that with increasing screw rotation increased level of crystallization of amylose-rich starch was observed, which influenced the mechanical properties of the final product. The relationship between the extruder-cooker screw rotation and the rheological properties of the processed liquefied blend was also demonstrated in other studies (Tolstoguzov, 1993). The

(C) 2017 Institute of Agrophysics, Polish Academy of Sciences 
functional properties of thermoplastic starch (TPS) depend on the quantity and type of added plasticizers and auxiliary materials, as well (Combrzyński et al., 2012; Mitrus et al., 2010; Mościcki et al., 2007). The best improvement of TPS mechanical properties was obtained with glycerol, as materials became more pliable and easier to work. The structure of a TPS surface depends to a great extent on the starch type used. TPS materials obtained from potato starch exhibited a relatively smooth structure and gradual smoothing of the surface with increasing glycerol content. Pores are the results of excessive granulate expansion during barothermal extrusion-cooking, creating a characteristic honey comb structure (Janssen and Mościcki, 2009).

This paper provides an approach aimed at examining water vapour sorption properties of TPS loose-fill cushioning foams, enriched with two foaming agents: poly(vinyl alcohol) PVA and Plastronfoam PDE. A systematic study of the sorption and adhesion properties of TPS materials will be performed to determine their possible usage as biodegradable packaging materials and its behavior during storage.

\section{MATERIALS AND METHODS}

Potato starch of the Superior Standard type (PPZ Trzemeszno, Trzemeszno, Poland) was used in this study. The water content of the starch was $16.7 \%$ and the $\mathrm{pH} 7.4$. As the foaming agents: Plastronfoam PDE (VGT Polska Sp. z o.o., Kraków, Poland) and poly(vinyl alcohol) PVA (Avantor-POCH S.A, Gliwice, Poland) were used in amount of 1,2 and $3 \%(\mathrm{w} / \mathrm{w})$. In total, 7 various starchfoaming agent blends were prepared. The control blend, containing only potato starch and experimental blends, enriched with a PVA or PDE foaming agents were prepared and moistened up to $18 \%$. The blends were mixed for $20 \mathrm{~min}$ in a laboratory ribbon mixer (type 357651, Rowag Rogoźno Wlkp., Poland) until homogeneous mass was obtained.

The extrusion-cooking process was carried out using a single screw extruder-cooker TS-45 (Z.M.Ch. Metalchem, Gliwice, Poland) with $\mathrm{L} / \mathrm{D}=12$. The screw rotation was set at 100 or 130 r.p.m., the temperature profile along the barrel sections (from the feeding zone to the die) was from 80 up to $100^{\circ} \mathrm{C}$. A forming circular die with the internal diameter of $5 \mathrm{~mm}$ was chosen for the experiment, and thus annular cross-section samples were obtained. Technological experiments were carried out in 3 repetitions. After the extrusioncooking, the foams were stabilized in room temperature, dried using the shelf dryer (self-constructed) for $24 \mathrm{~h}$ at $40^{\circ} \mathrm{C}$ in natural air convection and stored in closed bags before tests. The coding scheme for the samples name is as follows: $\mathrm{XYZ}$, where $\mathrm{X}$ denotes the content of foaming agent $(1,2,3 \% \mathrm{w} / \mathrm{w}), \mathrm{Y}$ denotes the foaming agent type (C - control foam, PVA - poly(vinyl alcohol), PDE Plastronfoam), $\mathrm{Z}$ denotes the extruder screw rotation speed (100-100 r.p.m., 130-130 r.p.m.).
Determination of sorption isotherms was evaluated under various water activities conditions. The equilibrium water content of foam samples at $20^{\circ} \mathrm{C}$ was determined using the static gravimetric method. Samples weighing $c a$. $2 \mathrm{~g}$ were placed inside desiccators conditioned to a constant relative humidity $(\mathrm{RH})$ with saturated salt solutions in order to achieve a water activity range of $0.11-0.84$. The following salt solutions were used: $\mathrm{LiCl}\left(a_{w}=0.113\right)$, $\mathrm{KCH}_{3} \mathrm{COO} \quad\left(a_{w}=0.225\right), \quad \mathrm{MgCl}_{2} \quad\left(a_{w}=0.329\right), \quad \mathrm{K}_{2} \mathrm{CO}_{3}$ $\left(a_{w}=0.438\right), \operatorname{Mg}\left(\mathrm{NO}_{3}\right)_{2}\left(a_{w}=0.529\right), \mathrm{NaNO}_{2}\left(a_{w}=0.648\right)$, $\mathrm{NaCl}\left(a_{w}=0.753\right), \mathrm{KCl}\left(a_{w}=0.843\right)$, moreover, anhydrous $\mathrm{CaCl}_{2}$ was used to obtain $a_{w}=0.0$. Crystalline thymol was used to avoid the growth of mold in desiccators with relative humidity over $70 \%$. Desiccators were placed inside the thermostat cabinet for the period of 3 months, and after this period the weight change of each sample was determined. The analyses were performed for each foam type in triplicate, and the presented data represent mean values. The moisture adsorption data were fitted into the GAB model, defined as follows:

$$
u=\frac{u_{m} C k a_{w}}{\left[\left(1-k a_{w}\right) 1+(C-1) k a_{w}\right]}, \quad\left(\mathrm{g}_{\mathrm{H}_{2} \mathrm{O}} 100 \mathrm{~g}_{\text {d.b. }}{ }^{-1}\right)
$$

where: $u$ - the water equilibrium content $\left(\mathrm{g}_{\mathrm{H}_{2} \mathrm{O}} 100 \mathrm{~g}\right.$ of sample dry mass, d.b.), $u_{m}$ - the monolayer water content $\left(\mathrm{g}_{\mathrm{H}_{2} \mathrm{O}} 100 \mathrm{~g}_{\text {d.b. }}{ }^{-1}\right), a_{w}$ - the water activity of foam samples, $C$ - the kinetic constant related to the sorption in the first layer, $k$ - the kinetic constant related to multilayer sorption (Figura and Teixeira, 2007).

From the BET equation, the water activity of the monolayer water content was calculated (Oniszczuk et al., 2015). Finally, the specific surface area $a_{s p}\left(\mathrm{~m}^{2} \mathrm{~g}^{-1}\right)$ of the adsorbent was calculated according to the equation:

$$
a_{s p}=\frac{u_{m} \omega N}{M}, \quad\left(\mathrm{~g} \mathrm{~g}_{\mathrm{d} . \mathrm{b} .}{ }^{-1}\right)
$$

where: $a_{s p}$ - specific surface area $\left(\mathrm{m}^{2} \mathrm{~g}^{-1}\right), u_{m}$ - the monolayer water content ( $\left.\mathrm{g} \mathrm{g}_{\text {d.b. }}{ }^{-1}\right), N$ - the Avogadro number (6.023 $10^{23}$ molecules per mol), $\omega$ - the water setting surface (1.05 $10^{-19} \mathrm{~m}^{2}$ per molecule), $M$ - the water molecule mass (18.015 $\left.\mathrm{g} \mathrm{mol}^{-1}\right)$ (Figura and Teixeira, 2007).

The measurements of the water vapour sorption kinetics was performed by continuous recording of the foam weight values with the precision of $0.0001 \mathrm{~g}$, under constant relative humidity level and temperature. Before measurement the samples were dried for $24 \mathrm{~h}$ in a vacuum oven at $60^{\circ} \mathrm{C}$ to remove water. To maintain a constant relative humidity level the saturated solution of $\mathrm{NaCl}$ was used $(\mathrm{RH}=75.3 \%)$. The measurements were performed at $20^{\circ} \mathrm{C}$ for $18 \mathrm{~h}$ without access of light. In an attempt to describe the kinetics of water vapour adsorption, a two-parameter, non-exponential, empirical equation proposed by Peleg (1988) was used. The major advantage of the Peleg model is timesaving by 
predicting water sorption kinetics of materials, including equilibrium water content. In a modified form, it can be formulated as (Muszyński et al., 2016):

$$
M(t)=\frac{S_{0} M_{e} t}{M_{e}+t S_{0}}, \quad\left(\mathrm{~g} \mathrm{~g}_{\text {d.b. }}{ }^{-1}\right)
$$

where: $M(t)$ - the water content at the time $t\left(\mathrm{~g}_{\mathrm{H}_{2} \mathrm{O}} \mathrm{g}_{\mathrm{d} . b .}{ }^{-1}\right), S_{0}$ - equals the rate of moisture intake during the first period $(t=0)\left(\mathrm{g}_{\mathrm{H}_{2} \mathrm{O}} \mathrm{h}^{-1}\right), M_{e}$ - equal to the final equilibrium water content $(t=\infty)\left(\mathrm{g}_{\mathrm{H}_{2} \mathrm{O} \text { d.b. }}{ }^{-1}\right)$ (Turhan et al., 2002).

The statistical analysis of the models and equations fitting was performed on the base on experimental data. The parameters of the BET model and of the modified Peleg equation were determined with Table Curve 2D software (SYSTAT Software Inc., San Jose USA). The goodness of fit was assessed on the basis of the coefficient of determination $\mathrm{R}^{2}$, root mean square error RMS and coefficient of residual variation VCR (Nowacka et al., 2012).

\section{RESULTS AND DISCUSSION}

The relationship between the water activity and the equilibrium of the water content is shown by the isotherms (Fig. 1). The GAB model provided a very good
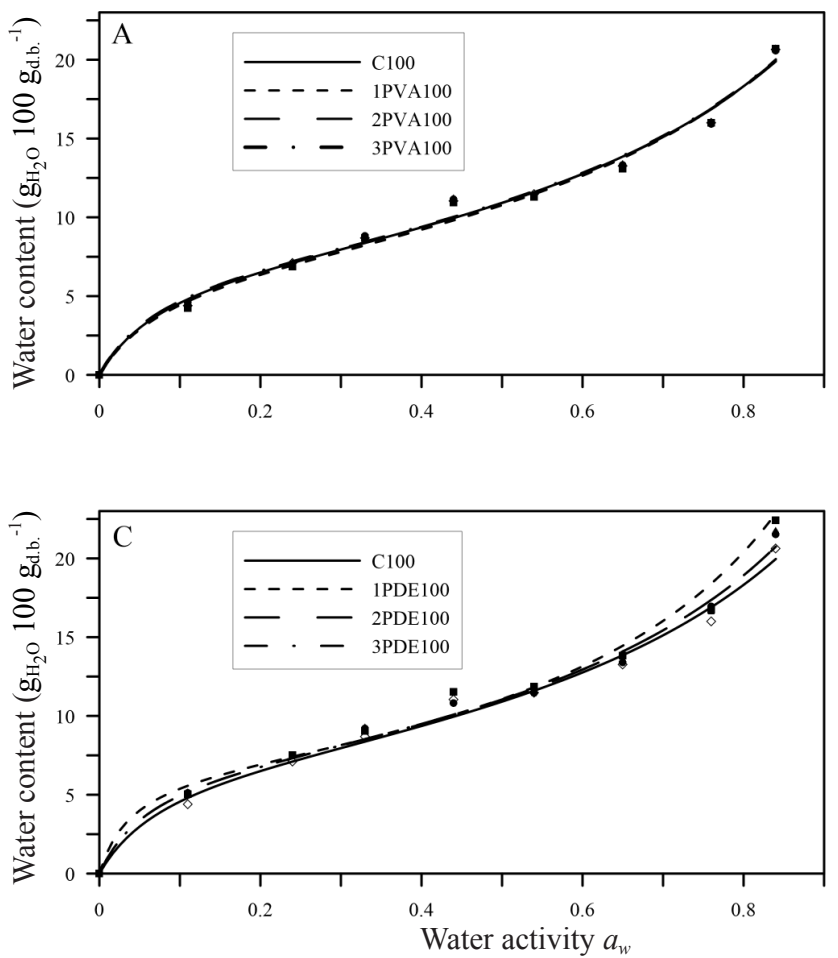

fit to the experimental sorption data for a whole range of water activity (Table 1) with the worst fit for 1PDE100 and $3 \operatorname{PDE} 100\left(\mathrm{R}^{2}=0.971\right.$ and $\mathrm{R}^{2}=0.977$, respectively). Further, the coefficient of residual variation showed the highest values for this two foams ( $\mathrm{VCR}=9.66$ and $8.15 \%$ for 1PDE100 and 3PDE100, respectively). However, as for all analysed foams RMS and VCR values are below 10 and $20 \%$, respectively it can be stated that BET model described the experimental data correctly. In general, there was no difference between the shapes of the isotherms for PVA foams (Fig. 1, panel A and B). With PDE foams, a notable difference for foams extruded at $100 \mathrm{rpm}$ was observed, especially in the regions of low and high humidity content (Fig. 1, panel C). Therefore, the parameter $\mathrm{C}$ in the $\mathrm{GAB}$ equation, related to the sorption in the first layer, has the greatest values for PDE100 foams (Table 1). In the middle region of water activity, where the complete moisture monolayer is formed, the shape of the isotherm was similar for all foams. However, the calculated monolayer capacity $u_{m}$ was the lowest for 1PDE100 foam (Table 1). In general, for the control and all PVA foams, the monolayer capacity $u_{m}$, the water activity of monolayer and the specific surface area $a_{s p}$ were greater when foams were extruded at the screw speed of 100 r.p.m. than at 130 r.p.m. (Table 1). In contrast, for $1 \mathrm{PDE}$ and $3 \mathrm{PDE}$ foams the increase of
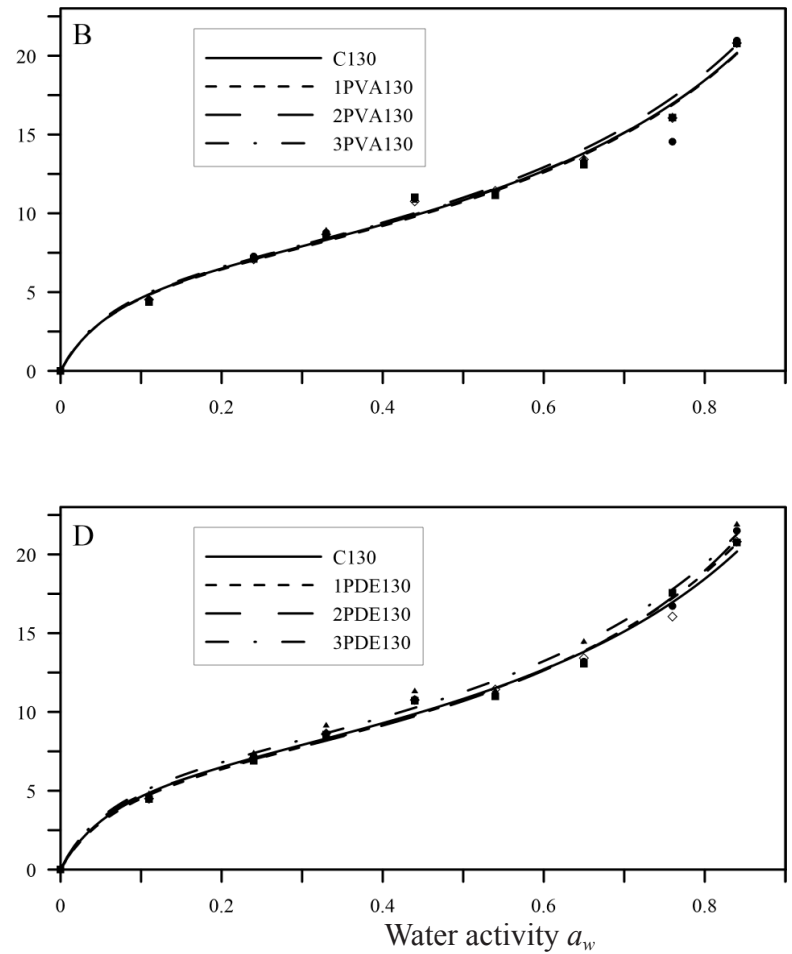

Fig. 1. Sorption isotherms for different types of starch foams (points) approximated with the GAB model (lines). A - control foam (C100) and foams enriched with 1\% (1PVA100), 2\% (2PVA100) or 3\% (3PVA100) of poly(vinyl alcohol) PVA extruded at the extruder screw speed of 100 r.p.m.; B - control foam (C130) and foams enriched with 1\% (1PVA130), 2\% (2PVA130) or 3\% (3PVA 130 ) of poly(vinyl alcohol) PVA extruded at the extruder screw speed of 130 r.p.m.; C - control foam (C100) and foams enriched with 1\% (1PDE100), 2\% (2PDE100) or 3\% (3PDE100) of Plastronfoam PDE extruded at the extruder screw speed of 100 r.p.m.; D - control foam (C130) and foams enriched with 1\% (1PDE130), 2\% (2PDE130) or 3\% (3PDE130) of Plastronfoam PDE extruded at the extruder screw speed of 100 r.p.m. 
T a b l e 1. GAB equation parameters, the water activity of the monolayer and the surface area of adsorbent of foams stored at $20^{\circ} \mathrm{C}$

\begin{tabular}{|c|c|c|c|c|c|c|c|c|}
\hline \multirow{2}{*}{ Foam type } & \multicolumn{3}{|c|}{ GAB parameters } & \multicolumn{3}{|c|}{ Model accuracy } & \multirow{2}{*}{$\begin{array}{c}\text { Water activity } \\
\qquad a_{w} \text { of } \\
\text { monolayer }\end{array}$} & \multirow{2}{*}{$\begin{array}{c}\text { Specific surface } \\
\text { area } a_{a p} \\
\left(\mathrm{~m}^{2} \mathrm{~g}^{-1}\right)\end{array}$} \\
\hline & $\begin{array}{c}u_{m} \\
\left(\mathrm{~g}_{\mathrm{H}_{2} \mathrm{O}} 100 \text { gd.b. }{ }^{-1}\right)\end{array}$ & $C$ & $k$ & $\mathrm{R}^{2}$ & RMS\% & $\mathrm{VCR} \%$ & & \\
\hline $\mathrm{C} 100$ & 7.45 & 15.82 & 0.76 & 0.984 & 5.34 & 6.94 & 0.264 & 261.5 \\
\hline 1PVA100 & 7.32 & 15.15 & 0.77 & 0.982 & 5.85 & 7.36 & 0.265 & 257.0 \\
\hline 2PVA100 & 7.41 & 17.04 & 0.76 & 0.989 & 5.32 & 7.26 & 0.257 & 260.1 \\
\hline 3PVA100 & 7.44 & 16.55 & 0.76 & 0.981 & 5.05 & 7.47 & 0.260 & 261.2 \\
\hline 1PDE100 & 6.66 & 30.61 & 0.85 & 0.971 & 7.00 & 9.66 & 0.180 & 233.8 \\
\hline 2PDE100 & 7.21 & 20.00 & 0.79 & 0.988 & 4.27 & 5.97 & 0.231 & 253.1 \\
\hline 3PDE100 & 7.22 & 20.00 & 0.79 & 0.977 & 5.62 & 8.15 & 0.231 & 253.5 \\
\hline C130 & 7.23 & 17.11 & 0.78 & 0.987 & 4.64 & 6.13 & 0.250 & 253.8 \\
\hline 1PVA130 & 7.13 & 17.26 & 0.78 & 0.982 & 5.89 & 7.37 & 0.249 & 250.3 \\
\hline 2PVA130 & 7.33 & 16.53 & 0.78 & 0.985 & 5.22 & 6.23 & 0.253 & 257.3 \\
\hline 3PVA130 & 7.29 & 18.08 & 0.77 & 0.987 & 4.91 & 6.04 & 0.247 & 255.9 \\
\hline 1PDE130 & 7.09 & 16.29 & 0.79 & 0.990 & 4.54 & 5.64 & 0.251 & 248.9 \\
\hline 2PDE130 & 6.82 & 19.68 & 0.81 & 9.987 & 5.77 & 6.52 & 0.227 & 239.4 \\
\hline 3PDE130 & 7.40 & 18.28 & 0.79 & 0.984 & 5.01 & 6.84 & 0.240 & 259.8 \\
\hline
\end{tabular}

the screw speed resulted in the increase of those parameters. Also, the values of the $\mathrm{C}$ parameter of PVA foams differed from those of PDE, especially for foams extruded at 100 r.p.m., where it showed a considerably higher value for PDE foams (Table 1). The $k$ parameter, related to multilayer sorption, was similar for all foams, and ranged from 0.76 (C100) to 0.85 (1PDE100).

All sorption isotherms were of sigmoidal shape therefore can be classified as a type II according to Branauer classification. This type of isotherms is common for starchrich products (Marzec and Lewicki, 2006; Oniszczuk et al., 2015). The value of $C$ parameter is related to the sorption energies of the monolayer (Enrione et al., 2007). The comparison showed that the lower values were observed for the control foams and the foams extruded with a lower amount of foaming agents. That would suggest that water molecules in those types of foams are more weakly bound to the active site of the polymer matrix compared to the foams containing 2 or $3 \%$ of the foaming agent in their blends. As a result, the lower value of $C$ parameter, the higher value of monolayer water activity is generally observed (Table 1). Moreover, for all PDE foams, the $C$ constant of samples extruded at 100 r.p.m. was lower than of samples extruded at 130 r.p.m. This result suggests that the water molecules were less strongly bound with the foam surface of the foams extruded at a lower screw speed (Enrione et al., 2007; Figura and Teixeira, 2007). For the control and PVA foams this effect was not noticed. Furthermore, for all types of foams the $k$ parameter of the GAB equation was significantly lower than 1 . Therefore, it could be concluded that there was a difference between the energy associated with the isosteric heat of sorption in a multilayer and condensation of pure water, as the closer the value of $k$ parameter to 1 , the lower the mutual interaction between the absorbed water molecules in a multilayer is observed (Enrione et al., 2007).

Analyzing the shape of the moisture sorption curves (Fig. 2) as a function of time it can be concluded that all the foams absorb it in a similar manner and the parameters of the Peleg equation (Table 2) allow for a proper estimation of these properties. The adsorption curves are all of hyperbolic shape, and a very fit of the model to experimental data was achieved, as coefficient of residual variation VCR did not exceed the value of $20 \%$ in all cases. It is worth noting the for all PDE foams extruded at 100 r.p.m. the RMS\% exceeded the value of $10 \%(\mathrm{VCR}=16.60,12.45,12.48 \%$ for 1PDE100, 2PDE100 and 3PDE100, respectively). However, the worst fit in terms of root mean square error value was obtained for 3PDE130, where calculated RMS\% value reached $22.84 \%$.

For all samples, the foams exhibited typical adsorption behavior, absorbing moisture rapidly in the initial phase and slowing down as the water content began approaching equilibrium values. The highest initial sorption rate $\left(S_{0}\right.$ parameter) was observed for PDE foams, especially for 2PDE100 and 3PDE100 (0.108 and $0.087 \mathrm{~g}_{\mathrm{H}_{2} \mathrm{O}} \mathrm{h}^{-1}$, respectively). Furthermore, it can be noticed that for PVA foams extruded at 130 r.p.m. $S_{0}$ value was identical irrespectively of the PVA content in the extruded blend (ranging from 0.040 to $\left.0.041 \mathrm{~g}_{\mathrm{H}_{2} \mathrm{O}} \mathrm{h}^{-1}\right)$. The equilibrium water content $\left(M_{e}\right.$ parameter) during the $18 \mathrm{~h}$ long experimental run, was not achieved for any foam. (Table 2). The highest saturation with water vapour was observed for C100 an 1PDE130 foams, which reached in both cases about $86 \%$ of their theoretical equilibrium water content predicted by Peleg 

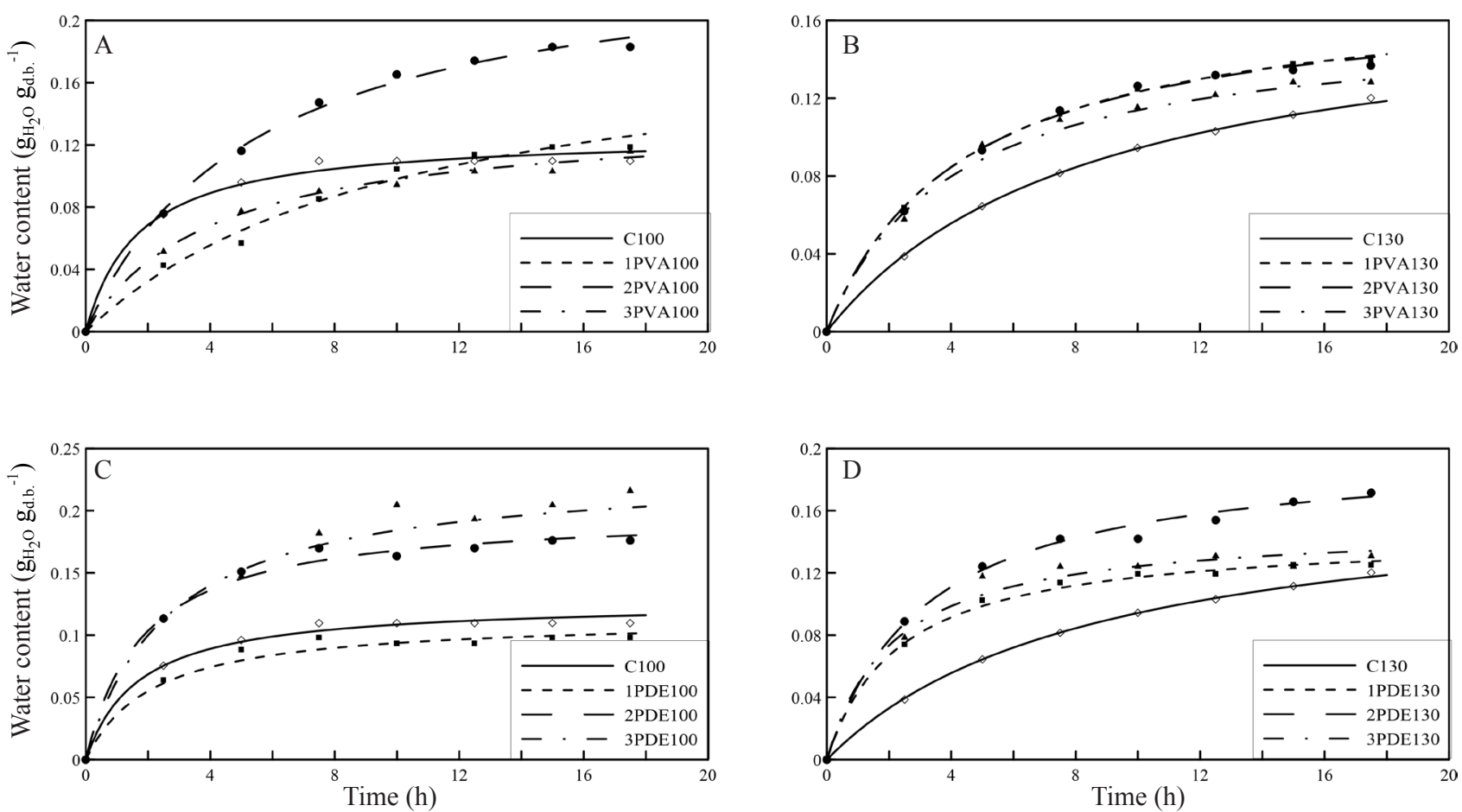

Fig. 2. Changes of water content as a function of the storage time of starch foams in $\mathrm{RH} 73.5 \%$ (points) approximated with Peleg equation (lines). A - control foam (C100) and foams enriched with 1\% (1PVA100), 2\% (2PVA100) or 3\% (3PVA100) of poly(vinyl alcohol) PVA extruded at the extruder screw speed of 100 r.p.m.; B - control foam (C130) and foams enriched with 1\% (1PVA130), 2\% (2PVA130) or 3\% (3PVA130) of poly(vinyl alcohol) PVA extruded at the extruder screw speed of 130 r.p.m.; C - control foam (C100) and foams enriched with 1\% (1PDE100), 2\% (2PDE100) or 3\% (3PDE100) of Plastronfoam PDE extruded at the extruder screw speed of 100 r.p.m.; D - control foam (C130) and foams enriched with 1\% (1PDE130), 2\% (2PDE130) or 3\% (3PDE130) of Plastronfoam PDE extruded at the extruder screw speed of 100 r.p.m.

T a b l e 2. Parameters of the modified Peleg equation of kinetics of water vapour adsorption for starch foams stored in RH $73.5 \%$

\begin{tabular}{|c|c|c|c|c|c|}
\hline \multirow{2}{*}{ Foam type } & \multicolumn{2}{|c|}{ Peleg equation parameters } & \multicolumn{3}{|c|}{ Model accuracy } \\
\hline & $\begin{array}{c}S_{0} \\
\left(\mathrm{~g}_{\mathrm{H}_{2} \mathrm{O}} \mathrm{h}^{-1}\right)\end{array}$ & $\begin{array}{c}M_{e} \\
\left(\mathrm{~g}_{\mathrm{H}_{2} \mathrm{O}} \mathrm{g}_{\mathrm{d} . b .}{ }^{-1}\right)\end{array}$ & $\mathrm{R}^{2}$ & $\mathrm{RMS} \%$ & VCR\% \\
\hline $\mathrm{C} 100$ & 0.074 & 0.127 & 0.978 & 4.52 & 3.89 \\
\hline 1PVA100 & 0.019 & 0.201 & 0.982 & 16.12 & 5.91 \\
\hline 2PVA100 & 0.046 & 0.248 & 0.996 & 2.52 & 2.17 \\
\hline 3PVA100 & 0.033 & 0.139 & 0.992 & 5.59 & 3.02 \\
\hline 1PDE100 & 0.053 & 0.114 & 0.944 & 16.60 & 7.11 \\
\hline 2PDE100 & 0.108 & 0.199 & 0.976 & 12.45 & 4.42 \\
\hline 3PDE100 & 0.087 & 0.233 & 0.941 & 12.48 & 7.66 \\
\hline $\mathrm{C} 130$ & 0.020 & 0.175 & 0.997 & 5.08 & 1.85 \\
\hline 1PVA130 & 0.040 & 0.177 & 0.999 & 1.23 & 1.07 \\
\hline 2PVA130 & 0.041 & 0.176 & 0.995 & 2.78 & 2.42 \\
\hline 3PVA130 & 0.040 & 0.159 & 0.992 & 7.37 & 3.15 \\
\hline 1PDE130 & 0.062 & 0.144 & 0.992 & 3.98 & 2.62 \\
\hline 2PDE130 & 0.062 & 0.200 & 0.988 & 9.13 & 3.58 \\
\hline 3PDE130 & 0.072 & 0.150 & 0.952 & 22.84 & 6.68 \\
\hline
\end{tabular}


model. Generally, the screw speed did not affect the adsorption rate in further phases or the final equilibrium of water content $\left(M_{e}\right.$ parameter) and for all types of foams the effect of initial moisture sorption rate $\left(S_{0}\right)$ on the final equilibrium water content $\left(M_{e}\right)$ was not found.

Water activity is one of the basic parameters characterizing the hygroscopic properties of the material (Figura and Teixeira, 2007). In systems that have not reached their equilibrium water activity a transport of water molecules occurs, which may alter the physical properties of the product. The effect of water on the texture of starch materials can be related to its plasticizing effects by increasing the free volume in the starch polymer (Enrione et al., 2007; Fontanet et al., 1997). Water molecules lead to the relaxation of the starch polymer structure, unveiling new active centers of adsorption. As a result, the extruded starch undergoes transition from its amorphous state to a viscoelastic state and the adsorption capacity increases (Fontanet et al., 1997; Marzec and Lewicki, 2006).

During the extrusion process starch forms amylose complexes, which reduce the availability of free sorption sites in amylose. Also, amylopectin as a highly-branched polymer is likely to have a number of water-binding sorption sites compared to amylose (Enrione et al., 2007). Therefore, the sorption capacity of the final product could also be related to the ratio of amylopectin to amylose in a given starch type. As the increase of water content or water activity increases molecular mobility it also could influence the resistance of the material to deformation (Marzec and Lewicki, 2006; Świetlicka et al., 2015). In our study, all foams had equilibrium water activity of monolayer below 0.300 . The additional humidification can lead to an increase in rigidity and brittleness, as a phenomenon of antiplasticization caused by water could occur (Marzec and Lewicki, 2006). Our further studies will be concerned with testing additional fillers to improve the hydrophobic characteristics of extruded foams in order to expand their usage in the packaging market.

\section{CONCLUSIONS}

1. The foams produced with various foaming agent content differed in terms of water vapour isotherms and moisture sorption.

2. In general, there was no difference between the shapes of the isotherms for foams containing poly(vinyl) alcohol.

3. With foams containing Plastronfoam, a notable difference for foams extruded at 100 r.p.m. was observed, especially in the regions of low and high humidity content.

4. In general, for the control and all foams containing poly(vinyl) alcohol, the monolayer capacity, the water activity of monolayer and the specific surface area were greater when foams were extruded at the screw speed of 100 than at 130 r.p.m.
5. All sorption isotherms were of sigmoidal shape therefore can be classified as a type II according to Branauer classification.

6. The water molecules were less strongly bound with the foam surface of the foams extruded at a lower screw speed.

7. For all samples, the foams exhibited typical adsorption behavior, absorbing moisture rapidly in the initial phase and slowing down as the water content began approaching equilibrium values. The highest initial sorption rate was observed for foams containing Plastronfoam.

8. The screw speed did not affect the adsorption rate in further phases or the final equilibrium of water content and for all types of foams the effect of initial moisture sorption rate on the final equilibrium water content was not found.

9. The extruded starch undergoes transition from its amorphous state to a viscoelastic state and the adsorption capacity increases.

Conflict of interest: Authors not declare conflict of interest.

\section{REFERENCES}

Agbisit R., Alavi S., Cheng E., Herald T., and Trater A., 2007. Relationships between microstructure and mechanical properties of cellular cornstarch extrudates. J. Texture Stud., 38, 199-219.

Altskär A., Andersson R., Boldizar A., Koch K., Stading M., Rigdahl M., and Thunwall M., 2008. Some effects of processing on the molecular structure and morphology of thermoplastic starch. Carbohydr. Polym., 71, 591-597.

Chanvrier H., Desbois F., Perotti F., Salzmann C., Chassagne S., Gumy J.C., and Blank I., 2013. Starch-based extruded cereals enriched in fibers: A behavior of composite solid foams. Carbohydr. Polym., 98(1), 842-853.

Combrzyński M., 2012. Biodegradability of thermoplastic starch. TEKA Commission Motorization and Power Industry Agric., 12(1), 21-25.

Combrzyński M., Mitrus M., Mościcki L., Oniszczuk T., and Wójtowicz A., 2012. Selected aspects of thermoplastic starch production. TEKA Commission of Motorization and Power Industry Agric., 12(1), 25-29.

Conti e Silva A.C., Da Cruz R.J., and Gomes Arêas J.A., 2010. Influence of thermoplastic extrusion on the nutritive value of bovine rumen protein. Meat Sci., 84, 409-412.

Enrione J.I., Hill S.E., and Mitchell J.R., 2007. Sorption and diffusional studies of extruded waxy maize starch-glycerol systems. Starch/Stärke, 59, 1-9.

Figura L.O. and Teixeira A.A., 2007. Food Physics: Physical Properties - Measurement and Applications. Springer Science \& Business Media, New York, USA.

Fontanet I.S. D., Dacremont C., and Le Meste M., 1997. Effect of water on the mechanical behaviour of extruded flat bread. J. Cereal Sci., 25, 303-311.

Frame N.D., 1994. The Technology of Extrusion Cooking. Blackie Academic Professional, New York, USA.

Guy R., 2001. Extrusion Cooking. Technologies and Applications. Woodhead Publishing Limited, Cambridge, UK. 
Ilo S., Liu Y., and Berghofer E., 1999. Extrusion cooking of rice flour and amaranth blends. Lebensm.-Wiss. Technol., 32, 79-88.

İbanoğlu Ş., Ainsworth P., Özer E.A., and Plunkett A., 2006. Physical and sensory evaluation of a nutritionally balanced gluten-free extruded snack. J. Food Eng., 75, 469-472.

Janssen L.P.B.M. and Mościcki L., 2009. Thermoplastic Starch. WILEY-VCH Verlag GmbH\&Co. KGaA, Weinheim, Germany.

Lui W.B. and Peng J., 2005. Physical, mechanical, biodegradable properties and energy absorption behavior of corn grit-polyvinyl alcohol cushioning extrudates. J. Food Eng., 71, 73-84.

Marzec A. and Lewicki P.P., 2006. Antiplasticization of cerealbased products by water. Part I. Extruded flat bread. J. Food Eng., 73, 1-8.

Mitrus M., 2012. Starch protective loose-fill foams. In: Thermoplastic Elastomers (Ed. A. El-Sonbati). InTech, Rijeka, Croatia, 79-94.

Mitrus M. and Mościcki L., 2014. Extrusion-cooking of starch procetive loose-fill foams. Chem. Eng. Res. Design, 92, 778-783.

Mitrus M., Wójtowicz A., and Mościcki L., 2010. Modification of potato starch by extrusion-cooking technique (in Polish). Acta Agrophysica, 16(1), 101-109.

Mościcki L., Mitrus M., and Wójtowicz A., 2007. ExtrusionCooking Technique in the Agri-Food Industry (in Polish). PWRiL, Warsaw, Poland.

Mościcki L. and Van Zuilichem D.J., 2011. Extrusion-cooking and related techniques. In: Extrusion-Cooking Techniques: Application, Theory and Sustainability (Ed. L. Mościcki). Wiley-VCH Verlag GmbH\&Co. KGaA, Wienhem, 1-24.

Muszyński S., Świetlicki M., Oniszczuk T., Kwaśniewska A., Świetlicka I., Arczewska M., Oniszczuk A., Bartnik G., Kornarzyński K., and Gladyszewska B., 2016. Effect of the surface structure of thermoplastic starch pellets on the kinetics of water vapor adsorption (in Polish). Przem. Chem., 95, 865-869.

Nowacka M., Janiak G., Kidoń M., Czapski J., and WitrowaRajchert D., 2012. Appluing mathematical models to describe water vapour adsorption isotherms of dried purple and orange carrots (in Polish). Żywn. Nauk. Technol. Jakość, 5(84), 60-72.

Oniszczuk T., Muszyński S., and Kwaśniewska A., 2015. The evaluation of sorption properties of thermoplastic starch pellets (in Polish). Przem. Chem., 94, 1752-1756.

Peleg M., 1988. An empirical model for the description of moisture sorption curves. J. Food Sci., 53, 1216-1217, 1219.

Suknark K., Phillips R.D., and Chinnan M.S., 1997. Physical properties of directly expanded extrudates formulated from partially defatted peanut flour and different types of starch. Food Res. Intern., 30(8), 575-583.

Świetlicka I., Muszyński S., and Marzec A., 2015. Extruded bread classification on the basis of acoustic emission signal with application of artificial neural networks. Int. Agrophys., 29, 221-229.

Tolstoguzov V.B., 1993. Thermoplastic extrusion - the mechanism of the formation of extrudate structure and properties. J. Amer. Oil Chem. Soc., 70, 417-424.

Turhan M., Sayar S., and Gunasekaran S., 2002. Application of the Peleg model to study water absorption in chickpea during soaking. J. Food Eng., 53, 153-159.

Van Soest J.J.G., De Wit D., and Vliegenthart J.F.G., 1996. Mechanical properties of thermoplastic waxy maize starch. J. App. Polym. Sci., 61, 1927-1937.

Wang L., Ganjyal G.M., Jones D.D., Weller C.L., and Hanna M.A., 2005. Modeling of bubble growth dynamics and nonisothermal expansion in starch-based foams during extrusion. Adv. Polymer Technol., 24(1), 29-45.

Wójtowicz A., Kolasa A., and Mościcki L., 2013. Influence of buckwheat addition on physical properties, texture and sensory characteristics of extruded corn snacks. Polish J. Food Nutr. Sci., 63(4), 239-244.

Wu M., Li D., Wang L.J., Özkan N., and Mao Z.H., 2010. Rheological properties of extruded dispersions of flaxseedmaize blend. J. Food Eng., 98, 480- 491. 